\title{
Investigating the effects of Pleistocene events on genetic divergence within Richardsonius balteatus, a widely distributed western North American minnow
}

\author{
Derek D Houston ${ }^{1,4^{*}}$, Dennis K Shiozawa², Brian Tilston Smith ${ }^{3,5}$ and Brett R Riddle ${ }^{1}$
}

\begin{abstract}
Background: Biogeographers seek to understand the influences of global climate shifts and geologic changes to the landscape on the ecology and evolution of organisms. Across both longer and shorter timeframes, the western North American landscape has experienced dynamic transformations related to various geologic processes and climatic oscillations, including events as recently as the Last Glacial Maximum (LGM; 20 Ka) that have impacted the evolution of the North American biota. Redside shiner is a cyprinid species that is widely distributed throughout western North America. The species' native range includes several well-documented Pleistocene refugia. Here we use mitochondrial DNA sequence data to assess phylogeography, and to test two biogeographic hypotheses regarding post-glacial colonization by redside shiner: 1) Redside shiner entered the Bonneville Basin at the time of the Bonneville Flood (Late Pleistocene; $14.5 \mathrm{Ka}$ ), and 2) redside shiner colonized British Columbia post-glacially from a single refugium in the Upper Columbia River drainage.

Results: Genetic diversification in redside shiner began in the mid to late Pleistocene, but was not associated with LGM. Different clades of redside shiner were distributed in multiple glacial age refugia, and each clade retains a signature of population expansion, with clades having secondary contact in some areas.

Conclusions: Divergence times between redside shiner populations in the Bonneville Basin and the Upper Snake/ Columbia River drainage precedes the Bonneville Flood, thus it is unlikely that redside shiner invaded the Bonneville Basin during this flooding event. All but one British Columbia population of redside shiner are associated with the Upper Columbia River drainage with the lone exception being a population near the coast, suggesting that the province as a whole was colonized from multiple refugia, but the inland British Columbia redside shiner populations are affiliated with a refugium in the Upper Columbia River drainage.
\end{abstract}

Keywords: Phylogeography, Redside shiner, Pluvial lakes, Glacial cycles, Climate change, Post-glacial colonization

\section{Background}

A major goal of biogeography is to investigate the influences of geological and climatic changes on the divergence and distribution of populations, species, and higher taxa. A reasonable expectation in biogeographic studies is that episodes of geographic isolation, and

\footnotetext{
* Correspondence: derek.d.houston@gmail.com

'School of Life Sciences, University of Nevada-Las Vegas, Las Vegas, NV 89154-4004, USA

${ }^{4}$ Current address: Department of Ecology, Evolution, \& Organismal Biology, lowa State University, Ames, IA 50011, USA

Full list of author information is available at the end of the article
}

consequently, opportunities for divergence should be favored on topographically complex landscapes $[1,2]$. The complex western North American landscape has a dynamic history of dramatic alterations resulting from tectonic processes as well as Pleistocene glacial cycles. These geological and climatic processes have influenced patterns of gene flow and diversification across a wide variety of taxa [3-9]. Such processes have heavily influenced the evolution of the North American fish fauna as well [10-15]. In western North America, the evolution of freshwater fishes has resulted from long term isolation of populations [16], 
but with intermittent dispersal occurring between hydrological basins for at least some taxa during major events such as stream captures and floods, some of which have been facilitated by climatic events [10,17-21].

Climatic oscillations during the Pleistocene have played a significant role in the evolution of the western North American biota by forcing organisms through a series of range contractions and expansions, range shifts, or localized extinctions as glacial ice sheets expanded and retracted [7]. In northwestern North America, refugia are postulated to have occurred in several areas, including Beringia [22-25], the Chehalis River Valley [4,26-28], the lower Columbia River drainage [29-31], the Upper Columbia River drainage [32-36], Haida Gwaii (a.k.a., Queen Charlotte Islands: an archipelago off the Pacific Coast of British Columbia) [37-39], and the KlamathSiskiyou region [5,36,40-42] (Figure 1). Additionally, some taxa have retained genetic signatures of survival in northern and southern refugia along the Pacific Coast $[27,43,44]$.

In addition to ice sheets, glacial-age lakes associated with the ice sheets altered the landscape of western North
American in ways that may have affected gene flow. Perhaps the best studied of these is Lake Missoula, a glacial lake that formed in western Montana when the Clark Fork River was dammed by a lobe of the Cordilleran Ice Sheet [45]. Catastrophic flooding occurred when the ice dam broke, and the rushing waters carved the channeled scablands of eastern Washington [18,45-47]. This process is hypothesized to have occurred approximately 40 (and perhaps as many as 100) times during the Pleistocene [48]. While most of those flooding events were small, some were catastrophic [48]. The highest magnitude Missoula floods were responsible for the capture of the Palouse River (from the Columbia River) by the lower Snake River, and the formation of Palouse Falls which now stand as a barrier to dispersal for aquatic taxa [49], likely affecting patterns of gene flow for many of the aquatic taxa in the area. Glacial floods were also responsible for completely filling the Willamette Valley in western Oregon [18], an event that appears to have influenced genetic structure for at least some taxa by forming a barrier between populations of terrestrial organisms [50], and possibly providing more connectivity of aquatic habitats and thus more

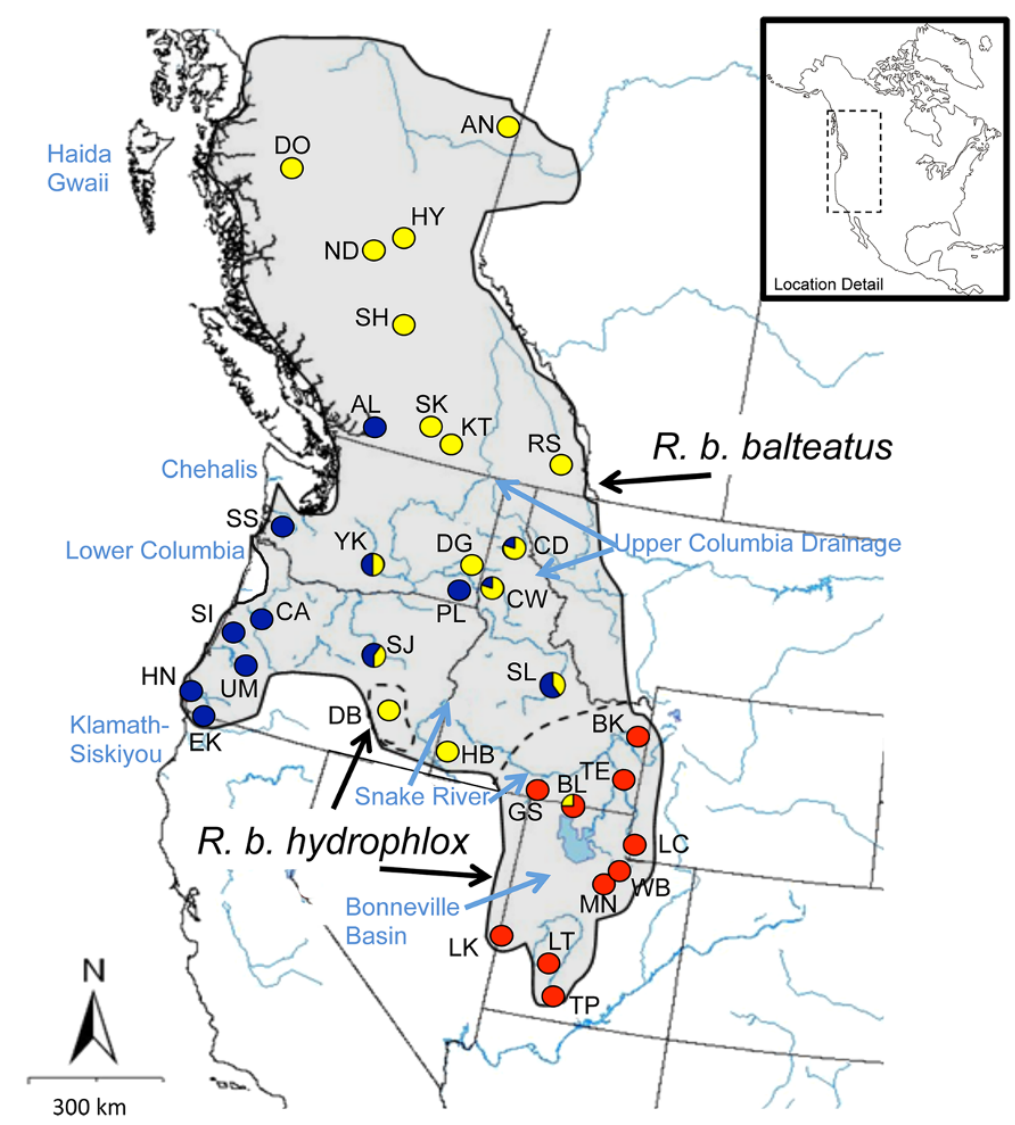

Figure 1 Distribution map for $\boldsymbol{R}$. balteatus. The dashed lines represent subspecies distribution boundaries. Circles represent sampling localities, and are color coded according to clade: Bonneville/Upper Snake (red), Northern Inland (yellow), and Pacific Northwestern lineages (blue). Population abbreviations correspond to those listed in Table 1. Six populations show a mixture of haplotypes, and the proportions are represented as pie charts. Documented Pleistocene refugia and major rivers are also labeled. 
opportunities for aquatic organisms to disperse. Glacial lakes and similar flooding events were also operating in northern areas (i.e., British Columbia) as the ice sheets retreated at the end of the Pleistocene [18].

The increased precipitation and decreased evaporation associated with glacial maxima resulted in the formation of pluvial lakes in many of the valleys of the Basin and Range province during the Pleistocene. Pluvial Lake Bonneville in the Bonneville Basin experienced lake high-stands coincident with glacial melt waters [51]. The highest level reached by Lake Bonneville is attributed to the capture of the Bear River from the Upper Snake River into the Bonneville Basin approximately 35,000 years ago [10,19,52]. The influx of water from the Bear River caused Lake Bonneville to rise until approximately 14,500 years ago when the lake breached a northern sill in Red Rocks Pass Idaho. Lake Bonneville drained catastrophically into the Upper Snake River in an event known as the Bonneville Flood [51,53]. This and similar pluvial lake outflows have been hypothesized to be important inter-basin transfer mechanisms for fish and other aquatic taxa $[19,54,55]$.

One western North American fish species, redside shiner Richardsonius balteatus (Richardson), occurs in many areas heavily influenced by Pleistocene climatic oscillations, either by glaciation directly, or by glacial and pluvial lakes. The species' native range spans the Bonneville Basin and the Snake-Columbia River basins west of the Rocky Mountains, ranging from southern Utah to northern British Columbia, and westward to the Pacific Coast of Oregon, Washington and British Columbia (Figure 1). Phylogenetic analyses based on mitochondrial DNA (mtDNA) data have demonstrated that $R$. balteatus is a monophyletic species that exhibits phylogeographic structure [55]. Pronounced morphological variation occurs among natural populations $[10,18,19]$. Variation in the number of anal fin rays, along with geographic distribution are the primary considerations for dividing the species into two subspecies, $R . b$. balteatus and $R . b$. hydrophlox. Such morphological variation could be the result of genetic differences resulting from historical isolation among populations, or of phenotypic plasticity in the face of different selective pressures in different environments. Moreover, subspecies $R . b$. hydrophlox exhibits geographic variation in somatic growth rates, at least some of which reflects genetic differences between populations [56].

Richardsonius balteatus is estimated to have diverged from its sister species, Lahontan redside shiner Richardsonius egregius (Girard), during the Pliocene [55,57], but genetic divergence within $R$. balteatus occurred more recently, during the early to mid Pleistocene and the species exhibits relatively shallow phylogenetic structure [55]. Such shallow structure is often attributed to influences of late Quaternary climatic shifts on patterns of gene flow. Because many parts of the current range of $R$. balteatus were affected by Pleistocene climatic oscillations, well-documented changes in hydrological connections are postulated to have influenced range expansion. The southernmost portion of the range, where $R . b$. hydrophlox occurs, includes the Bonneville Basin and Upper Snake River Plain (the subspecies also has disjunct populations in southeast Oregon; Figure 1).

Hubbs and Miller [54] postulated that R. balteatus invaded the Bonneville Basin from the Snake River at the time of the Bonneville Flood because it occurred above barrier falls in northern parts of its range. This proposed dispersal pathway is opposite to the direction of this massive flooding event, but Hubbs and Miller stated that fish moved in both directions through this connection. Their scenario of a southward invasion of the Bonneville Basin at the time of the Bonneville Flood is consistent with the fossil record, which shows that the extinct taxon $R$. durranti was present in Pliocene sediments of Lake Idaho [58], indicating that the genus occurred in the Snake River system in the Pliocene. The earliest known $R$. balteatus fossil in the Bonneville Basin is late Pleistocene in age [59]. However, fossil data merely place a minimum age for the occurrence of taxa in an area, so it is possible that $R$. balteatus entered the Bonneville Basin from the Snake River earlier in the Pleistocene, or has been in the Bonneville Basin for a much longer period of time. Molecular data have shown that both the Bear River capture and the Bonneville Flood transferred some freshwater fishes $[17,52]$, but the biogeography of other cyprinids suggests older (Miocene) connections between the Upper Snake River and Bonneville Basin existed [11,20,60,61].

Richardsonius balteatus populations in previously glaciated areas must have colonized post-glacially. It is hypothesized that $R$. balteatus colonized the northernmost parts of its range (i.e., British Columbia) post-glacially from a refugium in the Upper Columbia River Basin based on current distributions above barrier falls and several known geomorphic connections $[18,19]$. The Upper Columbia River drainage (including the Clearwater and Salmon rivers) is a hypothesized refugial area for fishes, amphibians, and plants [18,27,32,33,35], and could have been for $R$. balteatus as well. However, the current distribution of $R$. balteatus includes many proposed refugia other than the Upper Columbia River drainage, including the Chehalis River Valley, the lower Columbia River, and areas along the Oregon Coast. It is unknown whether R. balteatus colonized the aforementioned refugial areas post-glacially, or if the species occurred in one or more of them throughout the Pleistocene. Some phylogeographic evidence supports the latter scenario based on divergence times among three clades that date to the early to mid Pleistocene [55]. If the species did occur in Pleistocene refugia other than the Upper Columbia River drainage during the Pleistocene, 
then the species may have colonized northern environments from outside the Upper Columbia River system.

Herein, we use mtDNA sequence data to test two hypotheses regarding proposed range expansion events by $R$. balteatus: 1) We test the hypothesis that the species invaded the Bonneville Basin at the time of the Bonneville Flood [54] by assessing whether a pattern consistent with such a scenario exists. If $R$. balteatus did enter the Bonneville Basin at that time, then Bonneville Basin populations should exhibit signs of recent rapid expansion, and molecular dating estimates should be consistent with a late Pleistocene divergence time between Bonneville Basin populations and those in the Upper Snake/Columbia River drainage. 2) We test the hypothesis that $R$. balteatus colonized British Columbia post-glacially from a single refugium in the Upper Columbia River drainage [18]. If $R$. balteatus expanded northward into British Columbia from a single refugium, then genetic diversity in northernmost populations would be expected to be low, and should resemble that of the ancestral population. If $R$. balteatus expanded from multiple refugia, then haplotypes observed in previously glaciated areas should resemble those of each of the refugia from which $R$. balteatus dispersed. Furthermore, if $R$. balteatus expanded from multiple refugia, then greater genetic diversity would be expected in some populations representing suture zones where genetic admixture may have occurred. Lastly, we discuss an overview of the phylogeography of the species.

To test these hypotheses, we generated a phylogeny using maximum likelihood and Bayesian inference to assess the evolutionary relationships among redside shiner populations. We also generated a haplotype network to visualize the finer-scale phylogeographic structure. We estimated divergence times and evaluated changing population sizes through time to determine if divergence times and population expansions were consistent with late Pleistocene events.

\section{Methods}

\section{Sampling}

We compiled a dataset comprising 157 individuals from thirty-four populations throughout the native range of $R$. balteatus, along with $23 R$. egregius individuals from five populations that were used as the outgroup (Table 1). We used previously published DNA sequences from 28 of those populations [55], and generated DNA sequence data for 30 individuals from 6 additional populations. We sampled individuals from those six populations using a backpack electroshocker, a beach seine, or baited minnow traps. Once we sampled fish, we euthanized them by administering a lethal overdose of tricaine methanesulfonate (MS222 ), then immediately placed whole specimens into $95 \%$ ethanol to preserve tissues for genetic analyses. We placed the ethanol preserved samples on ice and transported them to the University of Nevada, Las Vegas (UNLV) where we assigned Monte L. Bean Life Science Museum (MLBM) catalogue numbers and Las Vegas Tissue (LVT) numbers to them before taking tissues for genetic analysis. All specimens were deposited in the MLBM fish collection as vouchers at the completion of this study, and all specimens also have a sample of muscle tissue stored in the LVT collection at UNLV. The UNLV Animal Care and Use Committee approved the protocols for the whole project, including the sampling and sacrificing of these minnows for the purpose of this research, as well as all subsequent handling of tissues/ DNA samples (IACUC Protocol \#R701-0703-179). We performed all collections under the appropriate state and provincial permits (issued to DDH and DKS).

\section{DNA extraction and polymerase chain reaction}

We extracted whole genomic DNA from muscle tissues using the manufacturer's recommended protocol for the Qiagen DNeasy tissue kit. We verified successful extractions qualitatively by viewing the DNA product under ultra-violet radiation following gel electrophoresis in a $0.8 \%$ agarose gel. We chose to amplify the control region (CR) and the cytochrome $b$ protein coding gene (cyt $b$ ) of the mitochondrial genome because they are rapidly evolving markers in fishes [62], but neither of them exhibits saturation in closely related cyprinid species [63-66], and therefore they should be useful in detecting phylogeographic structure caused by Pleistocene events. Moreover, gene sequences for many populations were already available [55]. We amplified both markers via the polymerase chain reaction (PCR) using the oligonucleotide primers HA-a and LA-a for cyt $b$ [67], and L-PRO and MRT-2 for CR $[68,69]$. We mixed reaction cocktails for PCR using approximately $100.0 \mathrm{ng}$ DNA template, 10.0 pmoles of each oligonucleotide primer, $2.25 \mu \mathrm{l}$ of molecular grade water, and $6.25 \mu \mathrm{l}$ of Promega GoTaq hot start green master mix for a total reaction volume of $12.5 \mu \mathrm{l}$. We used the following thermal profile for PCR: An initial denature of $95.0^{\circ} \mathrm{C}$ for four minutes, followed by thirty-five cycles of $95.0^{\circ} \mathrm{C}$ for 30 seconds, annealing at $50.0^{\circ} \mathrm{C}$ for 30 seconds, and extension at $72.0^{\circ} \mathrm{C}$ for 90 seconds, a final extension at $72.0^{\circ} \mathrm{C}$ for 7 minutes, and a rapid cool down to $4.0^{\circ} \mathrm{C}$. We verified successful PCR qualitatively by viewing bands of appropriate size following electrophoresis on $0.8 \%$ agarose gels. We purified PCR products using the manufacturer's recommended protocol for the Qiagen QiaQuick PCR purification kit.

\section{DNA sequencing and alignment}

We used the same primers for Sanger sequencing as we used for amplifying both markers, and sequenced light and heavy strands for each. We performed cycle sequencing reactions using Big Dye chemistry. Reaction cocktails 


\begin{tabular}{|c|c|c|c|c|c|}
\hline Sampling locality & Latitude/longitude & LVT \# & MLBM \# & GenBank \# & $\mathrm{N}$ \\
\hline \multicolumn{6}{|l|}{ BRITISH COLUMBIA } \\
\hline Alouette Lake (AL)*, & $49.290 \mathrm{~N}, 122.488 \mathrm{~W}$ & $9751-9755$ & $63987-63991$ & cyt b: KJ468400 - KJ468404 & 5 \\
\hline Fraser River Drainage & & & & CR: KJ468430 - KJ468434 & \\
\hline \multicolumn{6}{|l|}{ Lower Mainland Region } \\
\hline Antonelli Creek (AN), & $56.334 \mathrm{~N}, 120.154 \mathrm{~W}$ & $9721-9725$ & $63951-63955$ & cyt b: GU182709 - GU182713 & 5 \\
\hline Peace River Drainage & & & & CR: GU182504 - GU182508 & \\
\hline \multicolumn{6}{|l|}{ Peace Region } \\
\hline Doris Lake (DO), & $54.945 \mathrm{~N}, 126.552 \mathrm{~W}$ & $9731-9735$ & $63965-63969$ & cyt b: GU182743 - GU182747 & 5 \\
\hline Skeena River Drainage & & & & CR: GU182538 - GU182542 & \\
\hline \multicolumn{6}{|l|}{ Skeena Region } \\
\hline Hay Creek $(\mathrm{HY})^{*}$, & $54.074 \mathrm{~N}, 122.368 \mathrm{~W}$ & $9821-9825$ & $112018-112022$ & cyt b: KJ468405 - KJ 468409 & 5 \\
\hline Fraser River Drainage & & & & CR: KJ468435 - KJ 468439 & \\
\hline \multicolumn{6}{|l|}{ Omineca Region } \\
\hline Kettle River (KT), & $49.013 \mathrm{~N}, 118.200 \mathrm{~W}$ & $9001-9005$ & $084184-084188$ & cyt b: GU182777 - GU182781 & 5 \\
\hline Columbia River Drainage & & & & CR: GU182572 - GU182576 & \\
\hline \multicolumn{6}{|l|}{ Okanagan Region } \\
\hline Nadsilnich (West) Lake (ND)*, & $53.732 \mathrm{~N}, 122.859 \mathrm{~W}$ & $9831-9835$ & $112035-112039$ & cyt b: KJ468410 - KJ468414 & 5 \\
\hline Fraser River Drainage & & & & CR: KJ468440 - KJ468444 & \\
\hline \multicolumn{6}{|l|}{ Omineca Region } \\
\hline Rosen Lake (RS)*, & $49.402 \mathrm{~N}, 115.254 \mathrm{~W}$ & $9711-9715$ & $63940-63944$ & cyt b: KJ468415 - KJ468419 & 5 \\
\hline Columbia River Drainage & & & & CR: KJ468445 - KJ468449 & \\
\hline \multicolumn{6}{|l|}{ Kootenay Region } \\
\hline Shumway Lake $(\mathrm{SH})^{*}$, & $50.511 \mathrm{~N}, 120.264 \mathrm{~W}$ & $9811-9815$ & $112008-112012$ & cyt b: KJ468420 - KJ468424 & 5 \\
\hline Fraser River Drainage & & & & CR: KJ468450 - KJ468454 & \\
\hline \multicolumn{6}{|l|}{ Thompson Region } \\
\hline Similkameen River (SK), & $49.175 \mathrm{~N}, 119.768 \mathrm{~W}$ & $8991-8994$ & $84171-84175$ & cyt b: GU182838 - GU182841 & 4 \\
\hline Columbia River Drainage & & & & CR: GU182633 - 182636 & \\
\hline \multicolumn{6}{|l|}{ Okanagan Region } \\
\hline \multicolumn{6}{|l|}{ IDAHO } \\
\hline Big Bear Creek (Clearwater River; CW), & $46.600 \mathrm{~N}, 116.660 \mathrm{~W}$ & $8247-8251$ & $138772-138776$ & cyt b: GU182738 - GU182742 & 5 \\
\hline Columbia River Drainage & & & & CR: GU182533 - GU182537 & \\
\hline \multicolumn{6}{|l|}{ Latah County } \\
\hline Blackfoot River (BK), & $43.230 \mathrm{~N}, 112.030 \mathrm{~W}$ & $7851-7855$ & $58911-58915$ & cyt b: GU182714 - GU182718 & 5 \\
\hline Upper Snake River Drainage & & & & CR: 182509 - GU182513 & \\
\hline \multicolumn{6}{|l|}{ Bingham County } \\
\hline Cold Creek (Goose Creek; GS), & $42.093 \mathrm{~N}, 113.933 \mathrm{~W}$ & $7314-7318$ & $61222-61226$ & cyt b: GU182757 - GU182761 & 5 \\
\hline Upper Snake River Drainage & & & & CR: GU182552 - GU182556 & \\
\hline \multicolumn{6}{|l|}{ Cassia County } \\
\hline Coeur d'Alene River (CD), & $47.553 \mathrm{~N}, 116.257 \mathrm{~W}$ & $6301-6305$ & $63627-63631$ & cyt b: GU182733 - GU182737 & 5 \\
\hline Columbia River Drainage & & & & CR: GU182528 - GU182532 & \\
\hline \multicolumn{6}{|l|}{ Shoshone County } \\
\hline Hurry Back Creek (HB), & $42.581 \mathrm{~N}, 116.676 \mathrm{~W}$ & $7861-7865$ & $63743-63747$ & cyt b: GU182762 - GU182766 & 5 \\
\hline Lower Snake River Drainage & & & & CR: GU182557 - GU182561 & \\
\hline Owyhee County & & & & & \\
\hline
\end{tabular}




\section{Table 1 Sampling localities (Continued)}

\begin{tabular}{|c|c|c|c|c|c|}
\hline Salmon River (SL), & $44.639 \mathrm{~N}, 114.122 \mathrm{~W}$ & $7871-7875$ & $63780-63784$ & cyt b: GU182833 - GU182837 & 5 \\
\hline Lower Snake River Drainage & & & & CR: GU182628 - GU182632 & \\
\hline \multicolumn{6}{|l|}{ Custer County } \\
\hline Teton River (TE), & $43.750 \mathrm{~N}, 112.200 \mathrm{~W}$ & $7214-7218$ & $63688-63692$ & cyt b: GU182847 - GU182850 & 4 \\
\hline Upper Snake River Drainage & & & & CR: GU182642 - GU182645 & \\
\hline \multicolumn{6}{|l|}{ Teton County } \\
\hline \multicolumn{6}{|l|}{ OREGON } \\
\hline Callapooia River (CA), & $44.461 \mathrm{~N}, 123.076 \mathrm{~W}$ & $6291-6295$ & $63642-63646$ & cyt b: GU182728 - GU182732 & 5 \\
\hline Columbia River Drainage & & & & CR: GU182523 - GU182527 & \\
\hline \multicolumn{6}{|l|}{ Linn County } \\
\hline Callapooya Creek (Umpqua River; UM), & $43.413 \mathrm{~N}, 123.207 \mathrm{~W}$ & $8267-8271$ & $68425-68429$ & cyt b: GU182860 - GU182864 & 5 \\
\hline Pacific Ocean Drainage & & & & CR: GU182655 - GU182659 & \\
\hline \multicolumn{6}{|l|}{ Douglas County } \\
\hline Donner und Blitzen River (DB), & $42.801 \mathrm{~N}, 118.967 \mathrm{~W}$ & $9251-9255$ & $114035-114039$ & cyt b: GU182748 - GU182751 & 5 \\
\hline Harney Basin & & & & CR: GU182543 - GU182546 & \\
\hline \multicolumn{6}{|l|}{ Harney County } \\
\hline Elk Creek (EK), & $42.033 \mathrm{~N}, 123.750 \mathrm{~W}$ & $7334-7338$ & $59297-59301$ & cyt b: GU182752 - GU182756 & 5 \\
\hline Pacific Ocean Drainage & & & & CR: GU182457 GU182551 & \\
\hline \multicolumn{6}{|l|}{ Josephine County } \\
\hline Hunter Creek (HN), & $42.352 \mathrm{~N}, 124.353 \mathrm{~W}$ & $7234-7238$ & $63653-63657$ & cyt b: GU182767 - GU182771 & 5 \\
\hline Pacific Ocean Drainage & & & & CR: GU182562 - GU182566 & \\
\hline \multicolumn{6}{|l|}{ Curry County } \\
\hline South Fork John Day River (SJ), & $44.424 \mathrm{~N}, 119.540 \mathrm{~W}$ & $7224-7228$ & $63673-63677$ & cyt b: GU182823 - GU182827 & 5 \\
\hline Columbia River Drainage & & & & CR: GU182618 - GU182622 & \\
\hline \multicolumn{6}{|l|}{ Grant County } \\
\hline Siuslaw River (SI), & $44.000 \mathrm{~N}, 123.689 \mathrm{~W}$ & $8452-8456$ & $63929-63933$ & cyt b: GU182828 - GU182832 & 5 \\
\hline Pacific Ocean Drainage & & & & CR: GU182623 - GU182627 & \\
\hline \multicolumn{6}{|l|}{ Lane County } \\
\hline \multicolumn{6}{|l|}{ UTAH } \\
\hline Beaver Creek (Weber River; WB), & $40.626 \mathrm{~N}, 111.163 \mathrm{~W}$ & $8257-58,8260-61$ & 69873-74, 69876-77 & cyt b: GU182865 - GU182868 & 4 \\
\hline Bonneville Basin & & & & CR: GU182660 - GU182663 & \\
\hline \multicolumn{6}{|l|}{ Summit County } \\
\hline Blue Creek (BL), & $41.952 \mathrm{~N}, 112.723 \mathrm{~W}$ & $7300-7303$ & $68244-68247$ & cyt b: GU182719 - GU182722 & 4 \\
\hline Bonneville Basin & & & & CR: GU182514 - GU182517 & \\
\hline \multicolumn{6}{|l|}{ Box Elder County } \\
\hline Lake Creek (LK), & $38.767 \mathrm{~N}, 114.048 \mathrm{~W}$ & $7244-7248$ & $68439-68443$ & cyt b: GU182782 - GU182786 & 5 \\
\hline Bonneville Basin & & & & CR: GU182577 - GU182581 & \\
\hline \multicolumn{6}{|l|}{ Millard County } \\
\hline Little Reservoir (LT), & $38.250 \mathrm{~N}, 112.480 \mathrm{~W}$ & $7324-7328$ & $63718-63722$ & cyt b: GU182795 - GU182799 & 5 \\
\hline Bonneville Basin & & & & CR: GU182590 - GU182594 & \\
\hline \multicolumn{6}{|l|}{ Beaver County } \\
\hline Main Creek (MN), & $40.394 \mathrm{~N}, 111.442 \mathrm{~W}$ & $8042-8046$ & $63798-63802$ & cyt b: GU182810 - GU182814 & 5 \\
\hline Bonneville Basin & & & & CR: GU182605 - GU182609 & \\
\hline Wasatch County & & & & & \\
\hline Tropic Reservoir (TP), & $37.580 \mathrm{~N}, 112.250 \mathrm{~W}$ & $7284-7288$ & $63705-63709$ & cyt b: GU182855 - GU182859 & 5 \\
\hline
\end{tabular}


Table 1 Sampling localities (Continued)

\begin{tabular}{|c|c|c|c|c|c|}
\hline Bonneville Basin & & & & \multirow{2}{*}{ CR: GU182650 - 182654} & \\
\hline \multicolumn{5}{|l|}{ Garfield County } & \\
\hline \multicolumn{6}{|l|}{ WASHINGTON } \\
\hline Dragoon Creek (DG), & $47.887 \mathrm{~N}, 117.433 \mathrm{~W}$ & $7244-7248$ & $63183-63187$ & cyt b: GU182783 - GU182786 & 5 \\
\hline Columbia River Drainage & & & & CR: GU182577 - GU182581 & \\
\hline \multicolumn{6}{|l|}{ Spokane County } \\
\hline North Fork Palouse River (PL), & $46.920 \mathrm{~N}, 117.339 \mathrm{~W}$ & $8551-8555$ & $63622-63626$ & cyt b: GU182815 - GU182819 & 5 \\
\hline Lower Snake River Drainage & & & & CR: GU182610 - GU182614 & \\
\hline \multicolumn{6}{|l|}{ Whitman County } \\
\hline Satsop River (SS)*, & $46.999 \mathrm{~N}, 123.492 \mathrm{~W}$ & $9741-9745$ & $63976-63980$ & cyt b: KJ468425 - KJ468429 & 5 \\
\hline Chehalis River Drainage & & & & CR: KJ468455 - KJ468459 & \\
\hline \multicolumn{6}{|l|}{ Grays Harbor County } \\
\hline Yakima River (YK), & $46.417 \mathrm{~N}, 120.333 \mathrm{~W}$ & $7354-6,7358$ & $63583-5,63587$ & cyt b: GU182873 - GU182876 & 4 \\
\hline Columbia River Drainage & & & & CR: GU182668 - GU182671 & \\
\hline \multicolumn{6}{|l|}{ Yakama County } \\
\hline \multicolumn{6}{|l|}{ WYOMING } \\
\hline LaChappelle Creek (LC), & $41.127 \mathrm{~N}, 110.787 \mathrm{~W}$ & $8078-8081$ & $63810-63813$ & cyt b: GU182787 - GU182789 & 4 \\
\hline Bonneville Basin & & & & CR: GU182583 - GU182584 & \\
\hline Uinta County & & & & & \\
\hline
\end{tabular}

contained $3.0 \mu \mathrm{l}$ of purified PCR product, $12.2 \mu \mathrm{l}$ of molecular grade water, $3.2 \mu \mathrm{l}$ of $2.5 \mathrm{X}$ Tris buffer, $0.8 \mu \mathrm{l}$ of 25 $\mathrm{mM} \mathrm{MgCl}_{2}, 0.3 \mu \mathrm{l}$ of $10.0 \mu \mathrm{M}$ oligonucleotide primer, and $0.5 \mu \mathrm{l}$ of dye terminator reaction mix for an overall reaction volume of $20.0 \mu \mathrm{l}$. The thermal profile consisted of twenty-five cycles of $96.0^{\circ} \mathrm{C}$ for 10 seconds, $50.0^{\circ} \mathrm{C}$ for 5 sec, and $60.0^{\circ} \mathrm{C}$ for 5 minutes followed by a $4.0^{\circ}$ hold. In some cases it was necessary to use internal sequencing primers to complete the sequence, so for cyt $b$ we used either Sq7Hrs [55] or Sq3L [61], and for CR we used 12Rrs and $\mathrm{CR} 7 \mathrm{H}$ [55]. We removed excess dye terminators from cycle sequencing products using G-50 Fine Sephadex ${ }^{\mathrm{TM}}$ in Centri-Sep $^{\mathrm{TM}}$ spin columns, and performed all sequencing on an ABI 3130 automated sequencer.

We aligned sequences using the automatic assembly function in Sequencher v. 4.8 (Gene Codes Corp.) then inspected the aligned sequences by eye and made corrections manually. We used amino acid sequence and a $R$. balteatus cyt $b$ sequence [GenBank: AY096011] as references for aligning and editing cyt $b$ sequences. There were no gaps in the final cyt $b$ alignment, but there were in the final CR alignment. Individuals carried between three and five insertion/deletion sequences (each one bp long) in their non-coding CR sequences, but these were straightforward to align. Because both CR and cyt $b$ are in the mitochondrial genome, and are thus inherited as a unit, we concatenated the sequences prior to performing phylogenetic analyses.

\section{Phylogenetic analyses}

To get a broad assessment of redside shiner phylogeography, we generated phylogenies using maximum likelihood (ML) and Bayesian inference. We selected the appropriate model of sequence evolution to be used in the phylogenetic analyses using jModeltest [70], and we reconstructed the ML phylogeny using TreeFinder (version of 2008) [71]. We performed 1000 bootstrap replicates to estimate nodal support for ML analysis. In Bayesian analysis, we employed a Markov Chain Monte Carlo approach with one cold chain and three heated chains using the program MrBayes v.3.1.2 [72]. We ran the Bayesian analysis for 10,000,000 generations, sampling every 1000 generations. We verified that the analysis reached stationarity and evaluated mixing among chains using Tracer v.1.5.0 [73]. To get appropriate levels of mixing between chains we lowered the temperature setting to $\mathrm{T}=0.05$. We discarded the first $2,500,000$ generations (25\%) as burn-in, and obtained posterior probabilities using a majority rule consensus of the remaining topologies.

To better visualize intraspecific genetic variation within $R$. balteatus, we created a haplotype network using the software program TCS v.1.21 [74], using the default connection limit of $95 \%$ and treating gaps as a fifth character 
state. In some cases it was necessary to break loops among haplotypes that were not very divergent (but never among haplotypes spanning the three major clades), which we did using three criteria that are based on coalescent theory and are outlined by Kauwe et al. [75]. These three criteria are as follows: 1) Geography - haplotypes are more likely to be closely related to those from individuals with close geographic proximity than to those from individuals that were sampled from locations that are further away. 2) Topology - haplotypes are more likely to be closely related to those branching from basal nodes in a phylogeny than they are to be closely related to haplotypes that occur in the tips of a phylogenetic tree. 3) Frequency - haplotypes are more likely to be closely related to haplotypes that are shared than they are to be closely related to those that are carried by just one individual.

\section{Molecular dating estimation}

Molecular dating estimates allowed us to estimate whether divergence times between clades of redside shiner were consistent with the late Pleistocene time-frame of the phylogeographic hypotheses we sought to test. We performed molecular dating analyses using an uncorrelated lognormal relaxed clock in BEAST v. 1.7.5 [76] to estimate divergence times for clades within $R$. balteatus. We used the GTR + I + G model of sequence evolution (selected by jModelTest) and the coalescent constant model to set the prior on the tree. For the mutation rate prior distribution, we used a lognormal distribution with a mean rate of $1.4 \%$ sequence divergence per million years as estimated for Richardsonius, and specified a range of $1.0 \%$ to $2.4 \%$ sequence divergence per million years to cover the range of mutation rates for cyt $b$ for closely related genera [55] as well as reported mutation rates for $\mathrm{CR}$ in other cyprinids $[77,78]$. We ran the MCMC chain for 50,000,000 generations, sampling every 1000 generations, and discarded the first 5,000,000 generations as burn-in. We verified that the program reached stationarity and that there was proper mixing of chains by viewing the results in Tracer v.1.5.0 [79]. Trees were annotated using TreeAnnotator v.1.7.2 (part of the BEAST package) [76].

\section{Historical demography}

If redside shiner dispersed into the Bonneville Basin at the time of the Bonneville Flood, and into British Columbia from a single refugium as glaciers retreated, then redside shiner populations in these areas are predicted to exhibit signs of recent rapid expansion. We tested for recent rapid expansion in each of the three major redside shiner clades (see Results). To do so, we used BEAST v.1.7.5 [76] to generate Bayesian skyline plots that use coalescent modeling to infer population size over time [80,81]. We used a coalescent constant size tree prior, and employed a strict clock (with uniform rates across branches) using a uniform prior distribution with a mutation rate prior of $1.4 \%$ sequence divergence per million years [55], but allowing for a range of $1.0 \%$ to $2.4 \%$ sequence divergence per million years. We used the HKY substitution model of sequence evolution for each individual clade (based on the results of jModeltest). The model differed from that used in the phylogenetic analyses because model selection was run on each clade individually, and no outgroup taxa were included. We ran the analysis for 30 million generations, logging every 1000 generations, and discarded the first 3 million generations (10\%) as burn-in. Each of the three lineages was analyzed separately, but the parameters were the same for all three analyses. We performed the same MCMC diagnostics as described in our divergence time analysis.

\section{Results}

\section{DNA sequencing and alignment}

DNA sequencing yielded 1140 bp of cyt $b$ and $961 \mathrm{bp}$ of CR from $157 R$. balteatus individuals from 34 populations, and $23 R$. egregius individuals from five populations [55,57], for a total of 180 individuals. Of those 2101 characters, 1889 were invariable, 212 were variable, and 160 of the variable characters were parsimony informative. Ninetyseven unique mtDNA haplotypes were found among all sampled populations of $R$. balteatus. All DNA sequences are available in GenBank (see Table 1 for GenBank accession numbers).

\section{Phylogenetic analyses}

The jModeltest results selected the GTR $+\mathrm{I}+\mathrm{G}$ model of sequence evolution as the best fit for the concatenated mtDNA data set under the Akaike Information Criterion and the Bayesian Information Criterion. Phylogenies produced by ML and Bayesian analyses were similar, so only the ML phylogeny is shown, but ML bootstrap values and Bayesian posterior probabilities are mapped onto the nodes (Figure 2). For clarity, the major clades are presented in three different figures (Figures 3, 4 and 5).

Pacific Northwest populations do not form a wellsupported monophyletic clade although ML analysis did offer very weak support (ML bootstrap $=60$ ) for combining these lineages into a monophyletic group (Figure 2). The Pacific Northwestern clade was not supported in MrBayes analysis (but was recovered in our other analyses, including our Bayesian molecular dating estimates and haplotype network [see below]). Collapsing that node leads to a series of monophyletic lineages that stem from a basal polytomy for the species. Hereafter, we refer to these collective lineages as the Pacific Northwestern clade as a matter of convenience. Two well supported clades are nested within R. balteatus (Figure 2): One clade corresponds to individuals sampled from the Bonneville Basin and Upper Snake River drainage (Figure 3), and is hereafter referred 


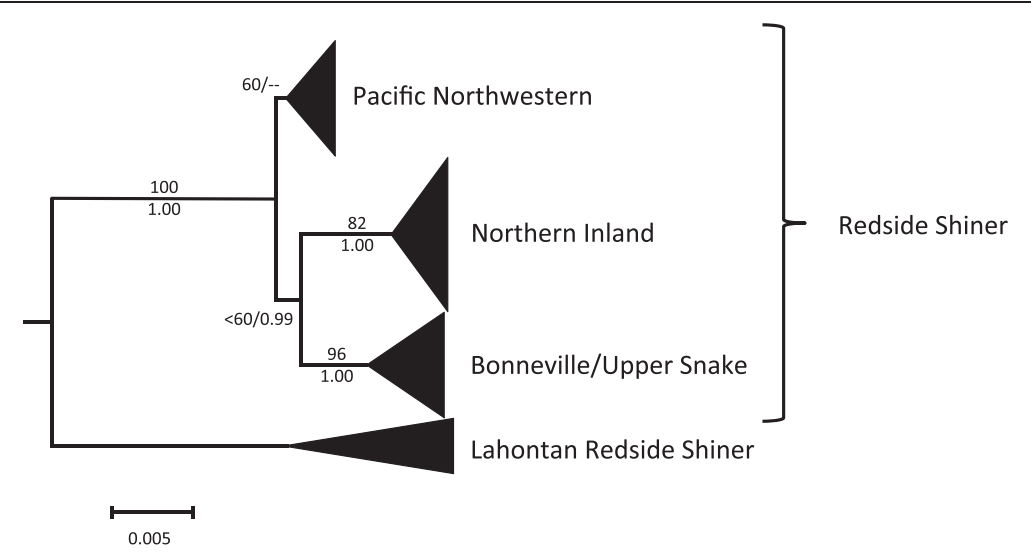

Figure 2 Redside Shiner Phylogeny. Phylogeny showing three major clades of redside shiner. Maximum likelihood bootstrap support values are listed above branches, and Bayesian posterior probabilities are listed below branches. The three clades are expanded for viewing in Figures 3, 4 and 5.

to as the Bonneville/Upper Snake Clade. The other, comprising individuals from inland populations along the Columbia Plateau and British Columbia (Figure 4), is hereafter referred to as the Northern Inland Clade. A sister relationship between the Northern Inland Clade and the Bonneville/Upper Snake Clade was supported by Bayesian analysis, but not by ML analysis (Figure 2). Collapsing that node would lead to a basal polytomy with Pacific Northwestern lineages, the Northern Inland Clade, and the Bonneville/Upper Snake Clade all stemming out of it. One individual sampled from the Bonneville system (BL 7300) carried a haplotype that is one base different from the most widespread haplotype found in the Northern Inland Clade (see Figures 1 and 6). Five other populations (Big Bear Creek, ID; Coeur d'Alene River, ID; Salmon River, ID; South Fork John Day River, OR; Yakima River, WA) contained individuals carrying divergent haplotypes from the Pacific Northwestern Clade and the Northern Inland Clade (see Figure 1).

A haplotype network shows intraspecific genetic variation within and among clades (Figure 6). Bonneville Basin/ Upper Snake River haplotypes are separated from Pacific Northwestern haplotypes by 15 steps, and southern Bonneville haplotypes are separated from northern Bonneville/Upper Snake River haplotypes by 12 steps. Northern Bonneville/Upper Snake River haplotypes exhibit a star-burst pattern. Haplotypes from the Northern Inland Clade are separated from haplotypes in the Pacific Northwestern Clade by 16 steps. A number of Northern Inland Clade haplotypes differ by one or two base pairs from the most widespread shared haplotype, and also exhibit a star-burst pattern, whereas other haplotypes within this clade (DB9254 and DB9255) are as divergent from the Northern Inland haplotype as they are from the Pacific Northwestern haplotypes. Some of the haplotypes from the Pacific Northwestern lineages
(SS9741 and SS9745) are 10 bp divergent from the other Pacific Northwestern haplotypes as well.

\section{Molecular dating estimation}

Molecular dating estimates show that divergence between $R$. balteatus and $R$. egregius occurred approximately $2.5 \mathrm{Ma}$ (Figure 7), well within the 95\% credible intervals for other divergence time estimates between the species [55,57]. Divergence within $R$. balteatus began approximately $0.88 \mathrm{Ma}$ (Figure 7 ). Diversification within the Bonneville/Upper Snake, Pacific Northwestern, and Northern Inland clades began almost simultaneously, with divergence time estimates of $0.44 \mathrm{Ma}, 0.46$ $\mathrm{Ma}$, and $0.43 \mathrm{Ma}$, respectively (Figure 7).

\section{Historical demography}

Bayesian skyline plots indicate that each of the three major clades experienced demographic expansions during the Pleistocene (Figure 8). The Bonneville/Upper Snake clade began expanding approximately 150,000 years before present, the Pacific Northwestern lineages were expanding prior to 300,000 years ago, and the most pronounced signature of expansion occurred in the Northern Inland clade, which began expanding approximately 50,000 years ago.

\section{Discussion}

Genetic diversification within $R$. balteatus occurred well within the Pleistocene, however most of it does not appear to have been associated with the LGM. Our results are inconsistent with a late Pleistocene colonization of the Bonneville Basin during the Bonneville Flood. Rather, molecular dating estimates show that divergence between northern and southern Bonneville clades was likely much earlier, approximately 440,000 years ago, and that the northern and southern Bonneville clades began diversifying 200,000 and 160,000 years before 


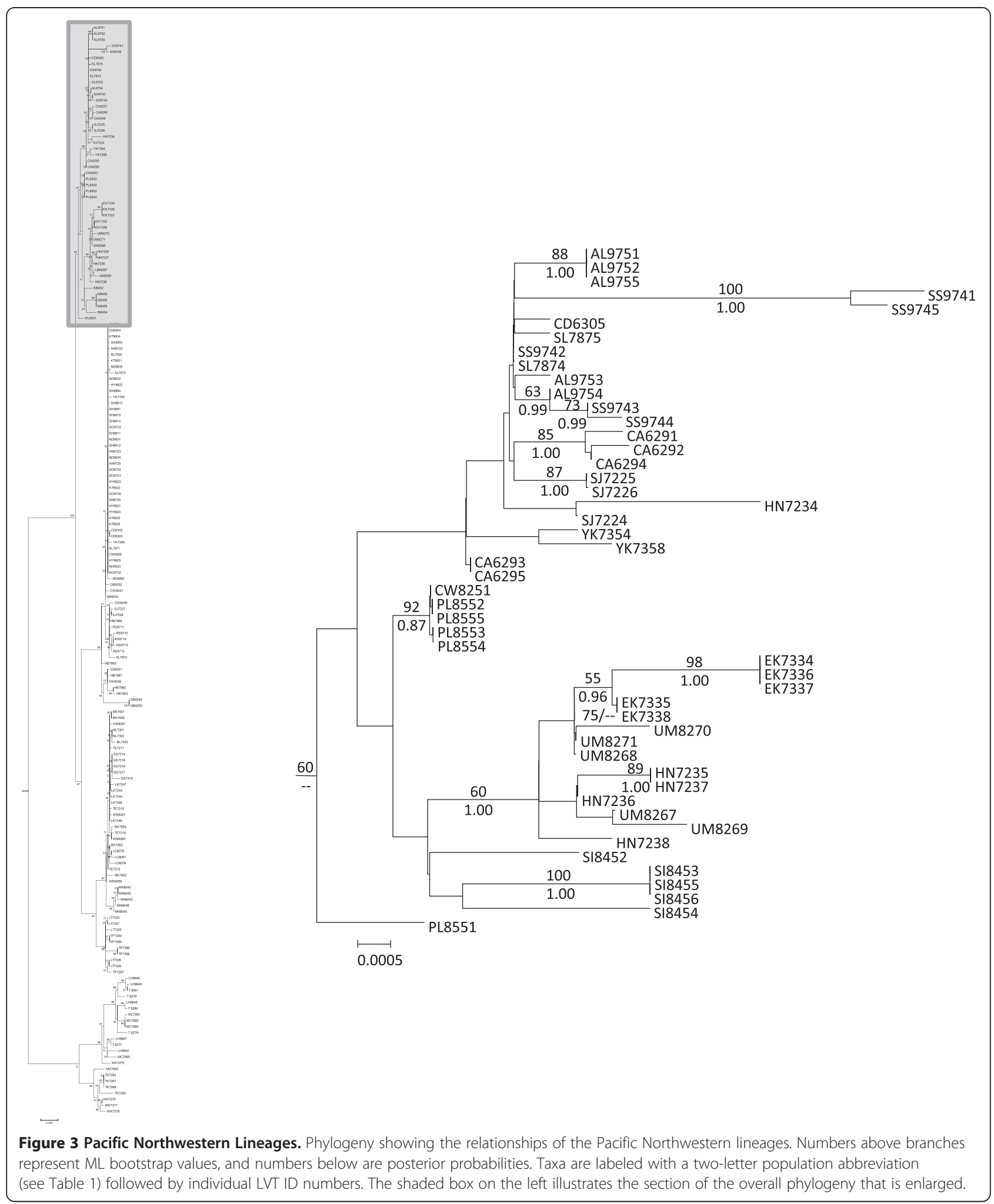

present, respectively (Figure 7). Despite the uncertainty surrounding molecular dating using mtDNA, the 95\% credible intervals surrounding these divergence time estimates did not include the Late Pleistocene when the
Bonneville Flood occurred. It is plausible that $R$. balteatus entered the Bonneville Basin during an earlier flooding event that connected the Snake River to the Bonneville Basin [82]. The earliest margin of the $95 \%$ credible interval 


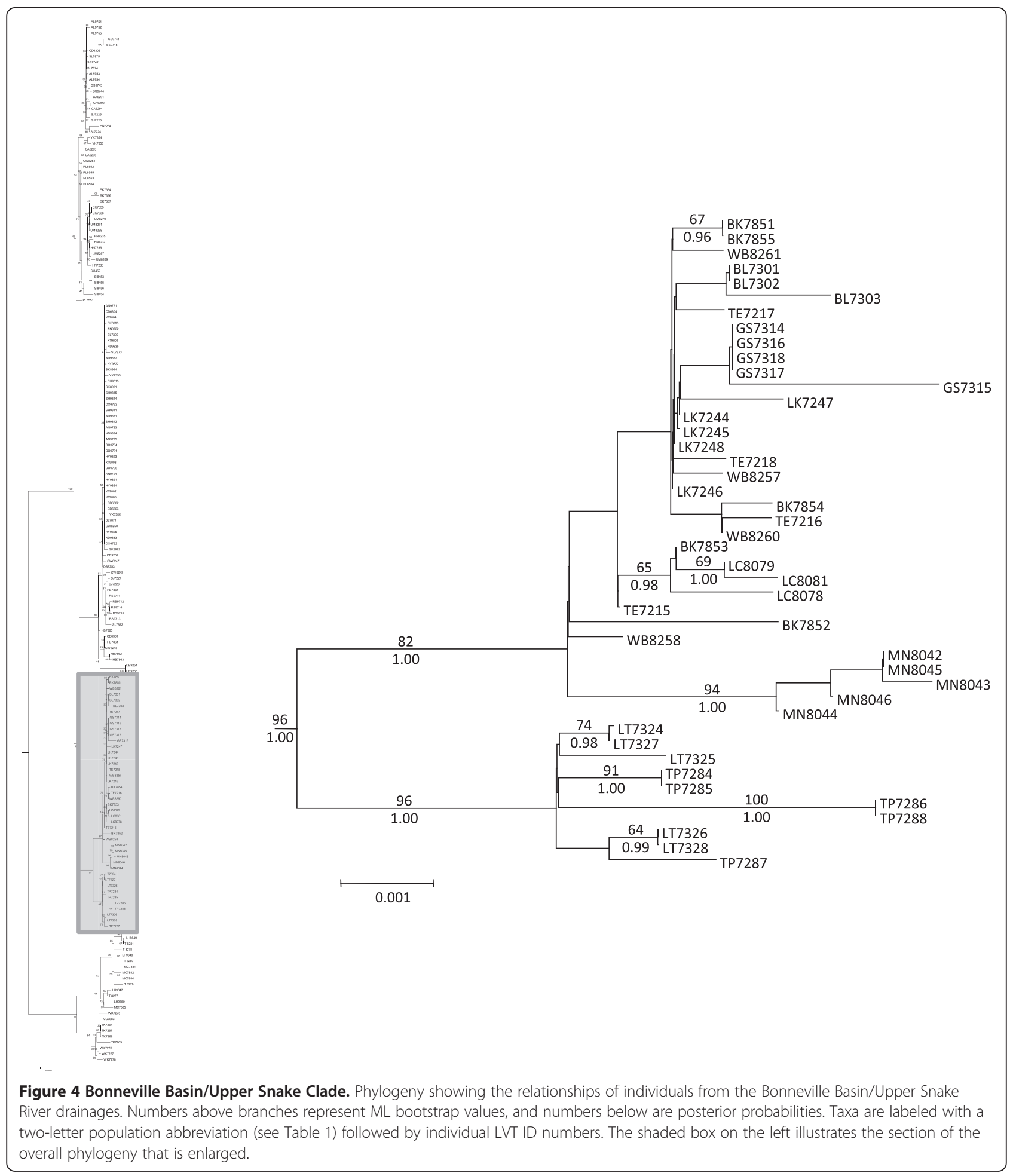

of this divergence time estimate overlaps with the presence of a large lake that formed in the Bonneville Basin approximately 650,000 years ago [83], although it remains unclear whether the catastrophic flooding event proposed by Ore [82] occurred at that time. The starburst pattern of northern Bonneville and Upper Snake
River haplotypes on the haplotype network (Figure 6) is suggestive that some northward dispersal from the Bonneville Basin into the Snake River at the time of the Bonneville Flood may have occurred. The development and use of more fine scale genetic markers would be useful in addressing this hypothesis. 


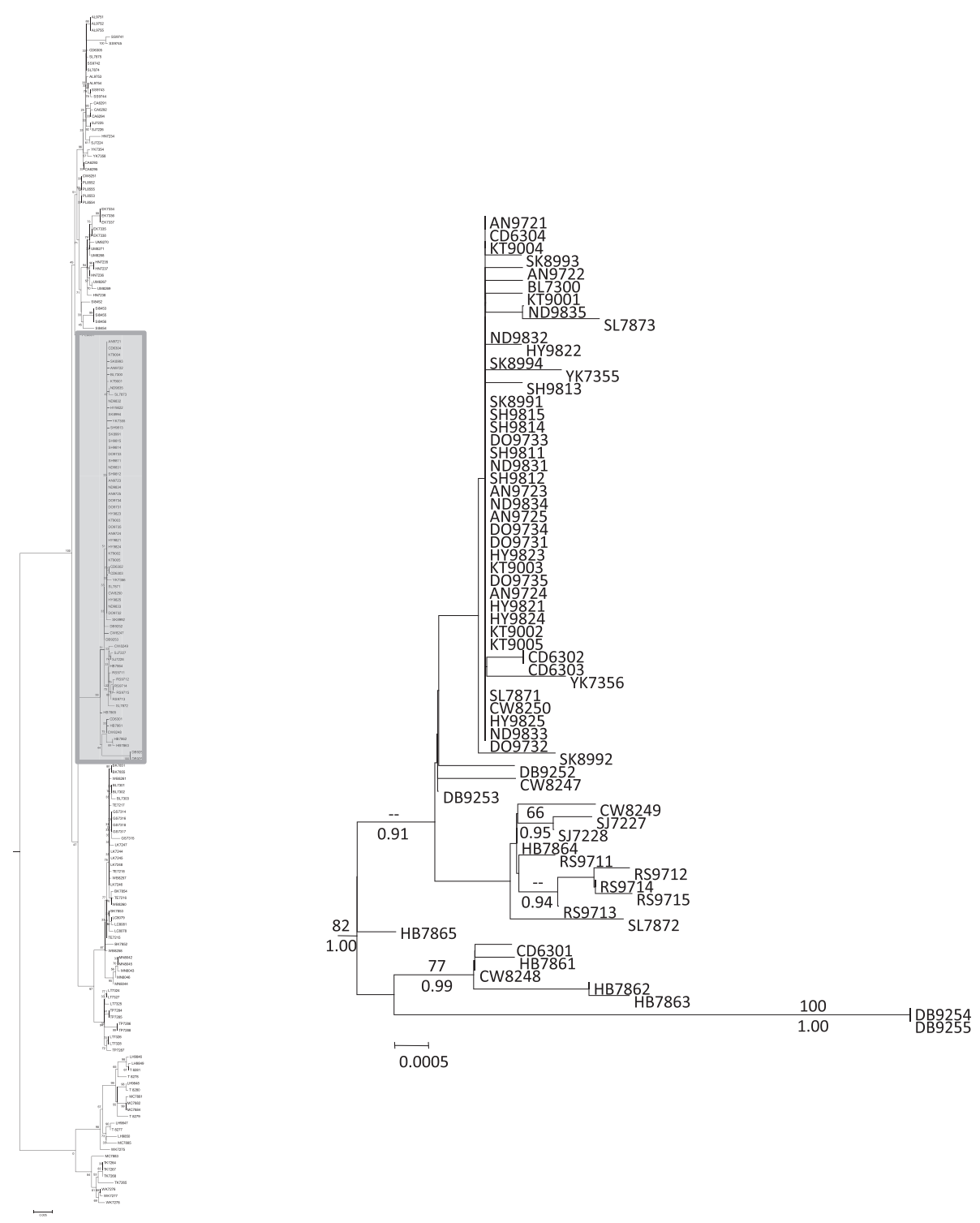

Figure 5 Northern Inland Clade. Phylogeny showing the relationships of individuals from the Upper Columbia drainages (including the lower Snake River) and inland British Columbia. Numbers above branches represent ML bootstrap values, and numbers below are posterior probabilities. Taxa are labeled with a two-letter population abbreviation (see Table 1) followed by individual LVT ID numbers. The shaded box on the left illustrates the section of the overall phylogeny that is enlarged.

Post-glacial colonization of most British Columbia sampling locations appears to have been from a single refugium in the Upper Columbia River drainage, with the lone exception being the Alouette Lake population east of Vancouver, BC. Individuals from Alouette Lake, which is in a Pacific Coastal drainage basin, were affiliated with lineages in the Pacific Northwestern clade (see Figure 1). The inland British Columbia populations all carried Northern Inland clade haplotypes (Figure 1), and the Northern Inland clade exhibited a pronounced signature of recent rapid demographic expansion (Figure 8). The star-burst pattern of many closely related haplotypes
(Figure 6) is consistent with this scenario. The low genetic diversity in these populations in previously glaciated areas is consistent with the prediction that genetic diversity should be low after having undergone recent rapid expansion. Hence, the phylogeographic scenario proposed by McPhail and Lindsey [18], wherein R. balteatus colonized British Columbia from a refugium in the Upper Columbia drainage via a series of connections between glacial lakes, is plausible. The Clearwater and Salmon Rivers of northern Idaho have been identified as Pleistocene refugia [32,33,35,84], and could have sheltered $R . b$. balteatus as well. 


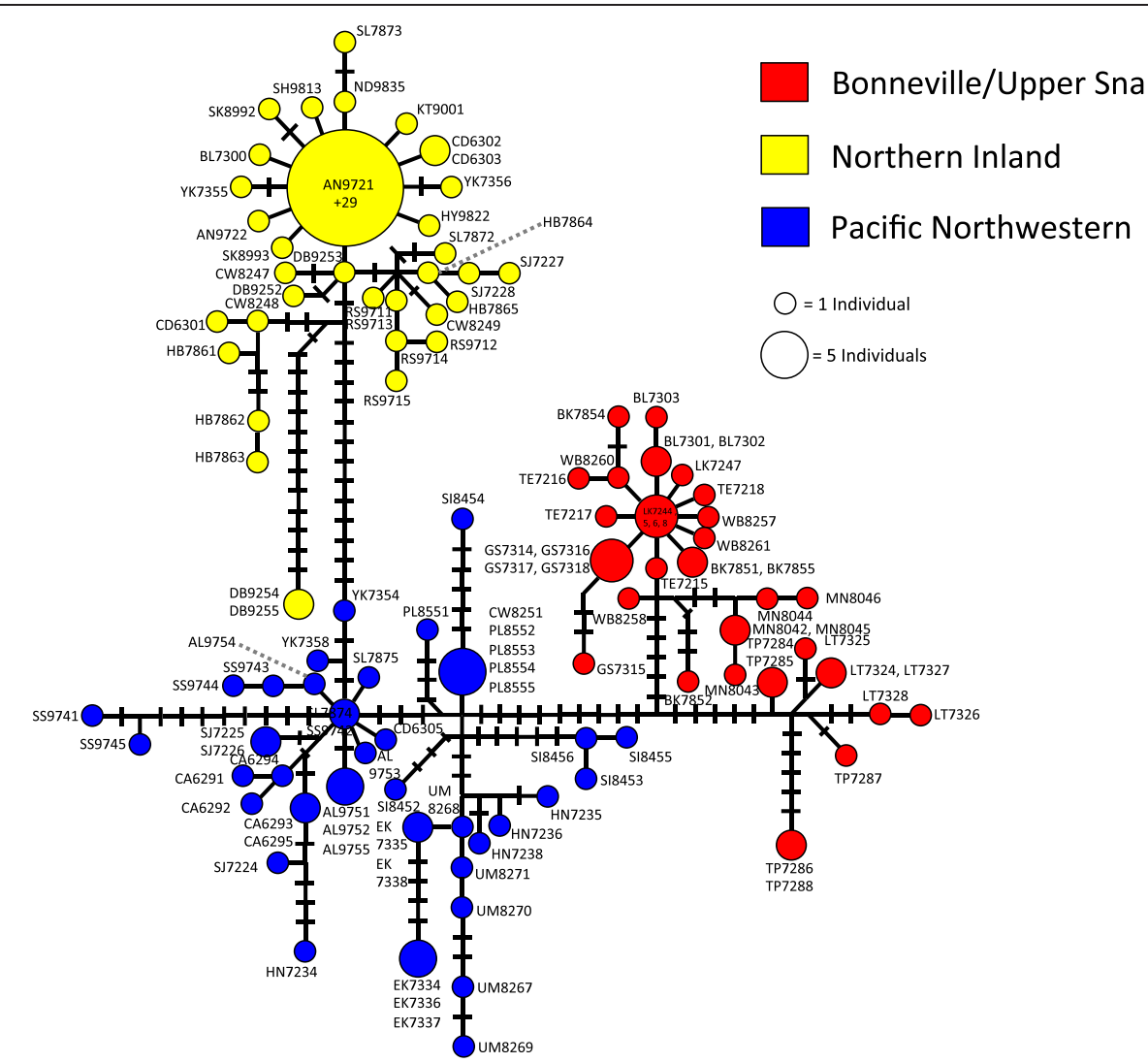

Figure 6 Redside shiner mtDNA haplotype network. Haplotype network showing the intraspecific genetic diversity for R. balteatus. Circles represent unique mtDNA haplotypes, and are color-coded corresponding to phylogenetic position. Circle size represents the number of individuals carrying each haplotype. Hash marks represent nucleotide base changes between haplotypes.

Secondary contact between Northern Inland clade and Pacific Northwestern lineages appears to have occurred in five populations in the Columbia River drainage (Coeur D’Alene River, Clearwater River, Salmon River, South Fork John Day River, and Yakima River; see Figure 1). We postulate that this secondary contact is relatively recent because there is no apparent admixture of mtDNA haplotypes in the populations that we sampled in British Columbia, suggesting that post-glacial colonization occurred prior to the two clades coming back into contact with one another. Moreover, several populations that are isolated by physical barriers to gene flow do not appear to have mixed mtDNA haplotypes. For example, coastal drainages (i.e., Elk Creek, Hunter Creek, Satsop River, Siuslaw River and Umpqua River) have not been connected to the main drainage of the Columbia Basin since the end of the Pleistocene [47], so gene flow has not been possible in recent times. Other populations (i.e., Callapooia River, Dragoon Creek and North Fork Palouse River) occur above barrier falls, or above seemingly impassable rapids, such as Hurry Back Creek (above Hell's Canyon along the Snake River). Such barriers seem to have prevented migrants from reaching these populations. Non-admixed populations above these barriers suggest that expansion of the clades did not occur until after the formation of these barriers. Palouse Falls (North Fork Palouse River), which formed during one of the more severe events associated with the Missoula floods, has a population above it containing only individuals affiliated with the Pacific Northwestern lineages. Another population in the Willamette Valley in Oregon (the Callapooia River, which is isolated from the lower Columbia River by another barrier falls) also contained haplotypes from the Pacific Northwestern lineages, so it is probable that Pacific Northwestern lineages were widespread during the Pleistocene. If the Missoula floods themselves were responsible for transferring individuals from the Northern Inland clade into habitats occupied by the Pacific Northwestern lineages, it does not appear to have done so during the most severe events such as the one that filled the Willamette Valley, otherwise the Callapooia River population above the falls would be expected to show genetic admixture as well, yet it does not.

It warrants mentioning that our sample sizes for each population are small (4 to 5 individuals per population), and may not have been sufficient to detect rare haplotypes in some areas. Additional sampling may reveal that non- 


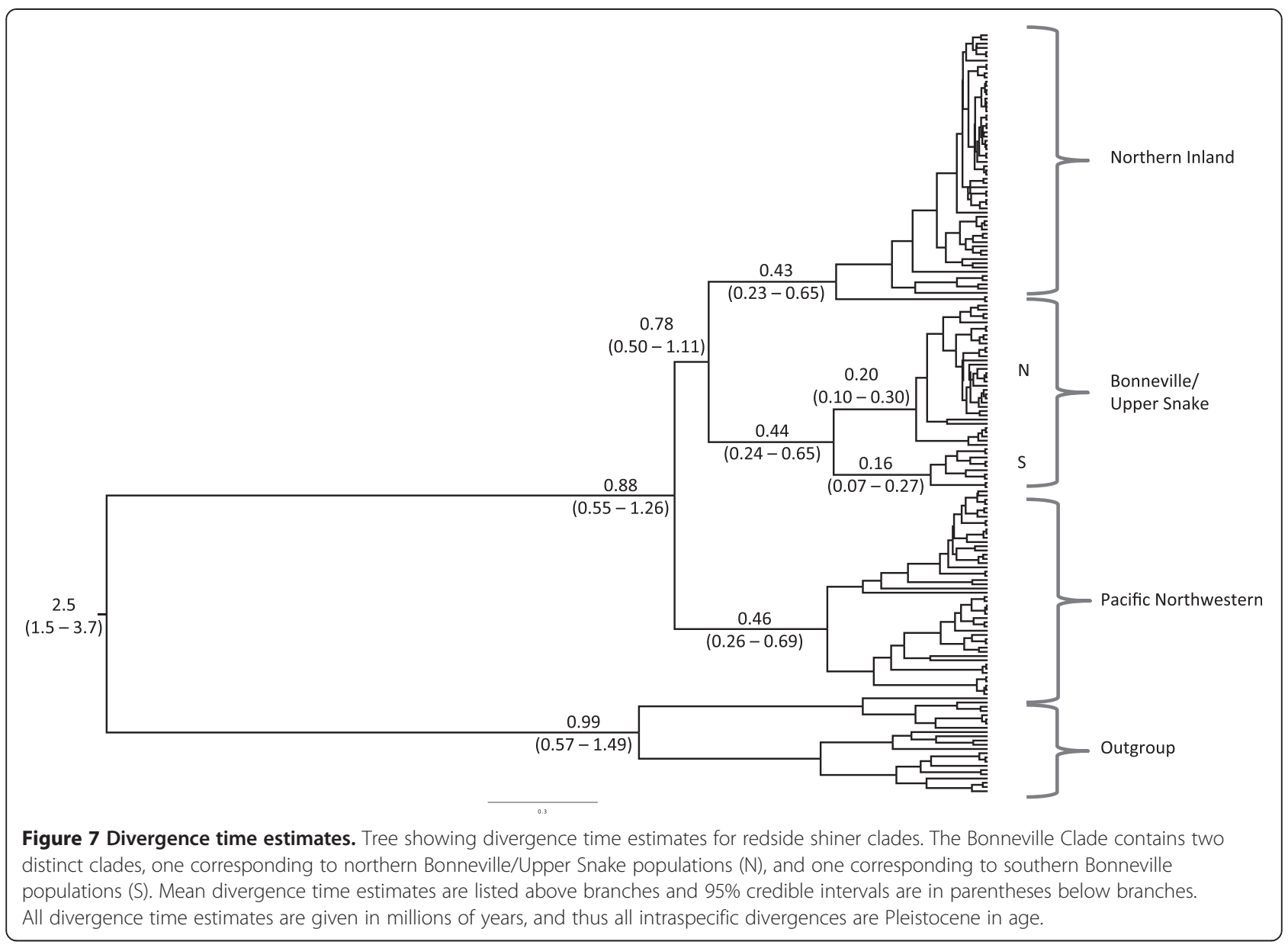

admixed populations above barriers also experienced secondary contact that we did not detect with our limited sampling. Additional sampling may also reveal areas in the Fraser River drainage where the Northern Inland Clade and Pacific Northwestern lineages have come into secondary contact. Individuals from a lower Fraser River population (Alouette Lake) have Pacific Northwestern haplotypes, whereas individuals from upper Fraser River populations (Hay Creek, Nadsilnich Lake, and Shumway Lake) carry Northern Inland haplotypes. This sampling bias is unlikely to change our conclusion that the inland British Columbia populations dispersed from a refugium in the Upper Columbia River drainage because all individuals from those populations had haplotypes associated with the Northern Inland Clade.

If $R . b$. balteatus did survive the Pleistocene in multiple refugia, as our data suggest, the locations appear to be in the lower Columbia River system and/or along the Pacific Coast, and somewhere in the Upper Columbia River drainage, as noted above. This scenario fits the biogeography of several other taxa. The lower Columbia River itself has been identified as a refugial area for various taxa [29-31,36,85-87], as have areas along the Pacific Coast, including the Chehalis River Valley in Washington State $[4,31,88]$. Unique haplotypes (SS9741 and SS9745) occur in the Satsop River within the Chehalis River Valley (Figure 6), but others (SS9742, SS9743, and SS9744) were more closely affiliated with other populations along the Pacific Coast. The existence of the two divergent haplotypes in the Satsop River, as well as the three that are associated with other Pacific Northwestern lineages suggests that the Chehalis River Valley may have been invaded by $R$. b. balteatus individuals from other areas, representing a unique instance where rather than expansion out of a Pleistocene refugium, the refugium may have been invaded instead. The Pacific Northwestern lineages were likely widespread during the Pleistocene given that they showed the earliest signs of population expansion (Figure 8), and that they range from the Pacific coastal drainages to as far inland as the North Fork Palouse River in eastern Washington (i.e., the nonadmixed population above Palouse Falls; Figure 1). Similarly, the Northern Inland Clade appears to have been widespread with populations ranging from the lower Snake River in southern Idaho to the upper Columbia drainage (Figure 1), although it appears that only the 


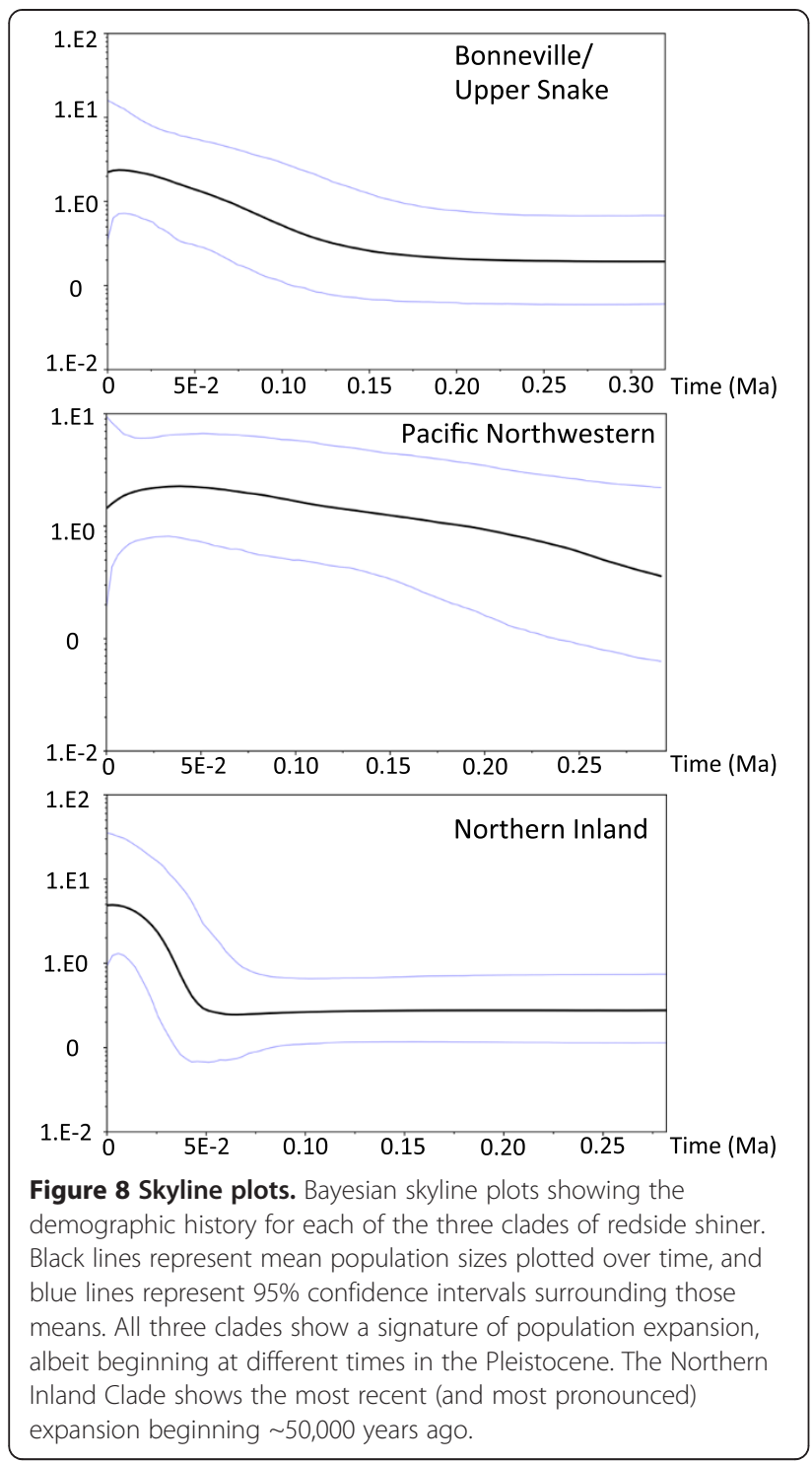

upper Columbia populations contributed to the postglacial colonization of inland British Columbia.

The timing of the Northern Inland Clade's expansion corresponds to the Wisconsin Glacial period (12 - 110 Ka) and into the Holocene, which is consistent with the idea of post-glacial expansion into inland British Columbia as the glaciers retreated. Population expansion of the Bonneville/Upper Snake Clade appears to be associated with the Illinoian Glacial period (130-200 Ka), or perhaps the Sangamonian interglacial $(110-130 \mathrm{Ka})$, which is not consistent with a late-Pleistocene invasion at the time of the Bonneville Flood. Expansion of the Pacific Northwestern lineages appears to be associated Pre-Illinoisan glacial cycles $(>200 \mathrm{Ka})$, as does the timing of the initial diversification within the species.
A single fish (BL7300) carrying a haplotype that nested well within the Northern Inland clade was sampled in a northern Bonneville Basin stream at the Utah/Idaho border. It may have been a "bait-bucket" transfer because no recent hydrological connections between that location (Blue Creek) and the middle Snake River are known and the required overland dispersal event from the nearest Columbia River location with its closely related haplotype (Salmon River) is over three hundred $\mathrm{km}$. Such "baitbucket" transfer incidents appear to be limited in our dataset, but are well known between the Bonneville Basin and Colorado River drainage of Utah $[89,90]$. Nevertheless, the biogeography of Richardsonius reflects historical distributions and drainage connections rather than recent anthropogenic introductions through most of its range, as is presumed to be the case for the majority of western North American freshwater fishes [60].

\section{Conclusions}

Diversification among redside shiner clades occurred during the Pleistocene, but the early divergences do not appear to be associated with the LGM. It is unlikely that the species entered the Bonneville Basin at the time of the Bonneville Flood as postulated by Hubbs and Miller [54]. All but one of the British Columbia populations are related to Upper Columbia River populations with the exception of Alouette Lake east of Vancouver, which is more closely related to coastal populations of redside shiner. Hence, the biogeographic scenario outlined by McPhail and Lindsey [18] is plausible. These conclusions are based on mtDNA data, and analyses using additional unlinked markers would greatly enhance our understanding of this system.

\section{Availability of supporting data}

The data set supporting the results of this article is available in the Dryad Digital Repository [doi:10.5061/ dryad.k2c2p] [91].

\section{Competing interests}

The authors declare that they have no financial or non-financial competing interests.

\section{Authors' contributions}

DDH, DKS, and BRR designed the study. DDH obtained field samples and generated DNA sequence data. DDH and BTS performed the data analyses. All authors contributed to the writing of the manuscript. All authors read and approved the final manuscript.

\section{Acknowledgements}

We thank the UNLV systematics research group for help with laboratory protocols and for analytical support. We thank John Klicka, Steve Rowland, and Javier Rodriguez for providing comments that improved early versions of this manuscript. Miguel Vences, Doug Markle and two anonymous reviewers provided comments that greatly improved the manuscript. This study was partially funded by several Graduate and Professional Student Association grants from UNLV to DDH, and by a Major Research Instrumentation Grant (DBI-0421519) to UNLV. 


\section{Author details}

'School of Life Sciences, University of Nevada-Las Vegas, Las Vegas, NV 89154-4004, USA. ²Department of Biology, Brigham Young University, Provo, UT 84602, USA. ${ }^{3}$ Museum of Natural Science, Louisiana State University, Baton Rouge, LA 70803, USA. ${ }^{4}$ Current address: Department of Ecology, Evolution, \& Organismal Biology, lowa State University, Ames, IA 50011, USA. ${ }^{5}$ Current address: Department of Ornithology, American Museum of Natural History, Central Park West at 79th Street, New York, NY 10024, USA.

\section{Received: 19 March 2014 Accepted: 12 May 2014}

Published: 23 May 2014

\section{References}

1. Vrba E: Mammals as a key to evolutionary theory. J Mammal 1992, 73:1-28.

2. Badgley C: Tectonics, topography, and mammalian diversity. Ecography 2010, 33:220-231.

3. Riddle BR: Molecular biogeography in the pocket mice (Perognathus and Chaetodipus) and grasshopper mice (Onychomys) - the late cenozoic development of a North-American aridlands rodent guild. J Mammal 1995, 76:283-301.

4. Soltis DE, Gitzendanner MA, Strenge DD, Soltis PS: Chloroplast DNA intraspecific phylogeography of plants from the Pacific Northwest of North America. Plant Syst Evol 1997, 206:353-373.

5. Brunsfeld SJ, Sullivan J, Soltis DE, Soltis PS: Comparative Phylogeography of Northwestern North America. In Integrating Ecology and Evolution in a Spatial Context. Edited by Silvertown J, Antonovics J. Malden, MA, USA: Blackwell Science Ltd; 2001:319-339.

6. Hershler R, Sada DW: Biogeography of Great Basin Aquatic Snails of the Genus Pyrgulopsis. In Great Basin Aquatic Systems History. Edited by Hershler R, Madsen DB, Currey DR, Smithsonian Contributions to the Earth Sciences Number 33. Washington DC: Smithsonian Institution Press; 2002:255-276.

7. Hewitt GM: Genetic consequences of climatic oscillations in the Quaternary. Philos Trans R Soc B 2004, 359:183-195.

8. Kohn MJ, Fremd TJ: Miocene tectonics and climate forcing of biodiversity, Western United States. Geology 2008, 36:783-786.

9. Hope AG, Speer KA, Demboski JR, Talbot SL, Cook JA: A climate for speciation: rapid spatial diversification within the Sorex cinereus complex of shrews. Mol Phylogenet Evol 2012, 64:671-684.

10. Minckley WL, Hendrickson DA, Bond CA: Geography of Western North American Freshwater Fishes: Description and Relationships to Intracontinental Tectonism. In The Zoogeography of North American Freshwater Fishes. Edited by Hocutt CH, Wiley EO. New York, NY: John Wiley and Sons; 1986:519-613.

11. Johnson JB, Dowling TE, Belk MC: Neglected taxonomy of rare desert fishes: congruent evidence for two species of leatherside chub. Syst Biol 2004, 53:841-855.

12. Berendzen PB, Simons AM, Wood RM, Dowling TE, Secor CL: Recovering cryptic diversity and ancient drainage patterns in eastern North America: historical biogeography of the Notropis rubellus species group (Teleostei: Cypriniformes). Mol Phylogenet Evol 2008, 46:721-737.

13. Blum MJ, Neely DA, Harris PM, Mayden RL: Molecular systematics of the cyprinid genus Campostoma (Actinopterygii: Cypriniformes): disassociation between morphological and mitochondrial differentiation. Copeia 2008, 2008:360-369.

14. April J, Hanner RH, Dion-Côté A-M, Bernatchez L: Glacial cycles as an allopatric speciation pump in north-eastern American freshwater fishes. Mol Ecol 2013, 22:409-422.

15. Unmack PJ, Dowling TE, Laitinen NJ, Secor CL, Mayden RL, Shiozawa DK, Smith GR: Influence of introgression and geological processes on phylogenetic relationships of western North American mountain suckers (Pantosteus, Catostomidae). PLoS One 2014, 9:e90061.

16. Smith GR: Late Cenozoic freshwater fishes of North America. Annu Rev Ecol Syst 1981, 12:163-193.

17. Mock KE, Evans RP, Crawford M, Cardall BL, Janecke SU, Miller MP: Rangewide molecular structuring in the Utah sucker (Catostomus ardens). Mol Ecol 2006, 15:2223-2238.

18. MCPhail JD, Lindsey CC: Zoogeography of the Freshwater Fishes of Cascadia (the Columbia System and Rivers North to the Stikine). In The Zoogeography of North American Freshwater Fishes. Edited by Hocutt CH, Wiley EO. New York, NY: John Wiley and Sons; 1986:615-638.
19. Smith GR, Dowling T, Gobalet K, Lugaski T, Shiozawa DK, Evans RP: Biogeography and Timing of Evolutionary Events Among Great Basin Fishes. In Great Basin Aquatic Systems History. Smithsonian Contributions to the Earth Sciences. 33rd edition. Edited by Hershler R, Madsen DB, Currey DR. Washington, DC: Smithsonian Institution Press; 2002:175-234.

20. Oakey DD, Douglas ME, Douglas MR: Small fish in a large landscape: diversification of Rhinichthys osculus (Cyprinidae) in western North America. Copeia 2004, 2004:207-221.

21. Chen YJ, Reid S, May B: Genetic relationships of tui chub populations in the Northwestern Great Basin and conservation implications for the Cow Head Tui Chub. Conserv Genet 2009, 10:101-114.

22. Hopkins DM, Smith PA, Matthews JV: Dated wood from Alaska and the Yukon - implications for forest refugia in Beringia. Quaternary Res 1981, 15:217-249.

23. Elias SA, Short SK, Nelson CH, Birks HH: Life and times of the Bering land bridge. Nature 1996, 382:60-63.

24. Pruett $\mathrm{CL}$, Winker $\mathrm{K}$ : Evidence for cryptic northern refugia among high- and temperate-latitude species in Beringia - a response to Stewart and Dalen (2008). Clim Change 2008, 86:23-27.

25. Aubry KB, Statham MJ, Sacks BN, Perrine JD, Wisely SM: Phylogeography of the North American red fox: vicariance in Pleistocene forest refugia. $\mathrm{Mol}$ Ecol 2009, 18:2668-2686.

26. MCPhail JD: Distribution of freshwater fishes in western Washington. Quaternary Sci 1967, 41:1-11.

27. Redenbach Z, Taylor EB: Evidence for historical introgression along a contact zone between two species of char (Pisces: Salmonidae) in Northwestern North America. Evolution 2002, 56:1021-1035.

28. Ross ST: Ecology of North American Freshwater Fishes. Berkeley: University of California Press; 2013

29. Bickham JW, Wood CC, Patton JC: Biogeographic implications of cytochrome-B sequences and allozymes in sockeye (Oncorhynchus-Nerka). $J$ Hered 1995, 86:140-144.

30. McCusker MR, Parkinson E, Taylor EB: Mitochondrial DNA variation in rainbow trout (Oncorhynchus mykiss) across its native range: testing biogeographical hypotheses and their relevance to conservation. Mol Ecol 2000, 9:2089-2108.

31. Haas GR, McPhail JD: The post-Wisconsinan glacial biogeography of bull trout (Salvelinus confluentus): a multivariate morphometric approach for conservation biology and management. Can J Fish Aquat Sci 2001, 58:2189-2203

32. Nielson M, Lohman K, Sullivan J: Phylogeography of the tailed frog (Ascaphus truei): implications for the biogeography of the Pacific Northwest. Evolution 2001, 55:147-160.

33. Carstens BC, Stevenson AL, Degenhardt JD, Sullivan J: Testing nested phylogenetic and phylogeographic hypotheses in the Plethodon vandykei species group. Syst Biol 2004, 53:781-792.

34. Carstens BC, Degenhardt JD, Stevenson AL, Sullivan J: Accounting for coalescent stochasticity in testing phylogeographical hypotheses: modelling Pleistocene population structure in the Idaho giant salamander Dicamptodon aterrimus. Mol Ecol 2005, 14:255-265.

35. Carstens BC, Brennan RS, Chua V, Duffie CV, Harvey MG, Koch RA, McMahan CD, Nelson BJ, Newman CE, Satler JD, Seeholzer G, Posbic K, Tank DC, Sullivan J: Model selection as a tool for phylogeographic inference: an example from the willow Salix melanopsis. Mol Ecol 2013, 22:4014-4028.

36. Steele CA, Storfer A: Coalescent-based hypothesis testing supports multiple Pleistocene refugia in the Pacific Northwest for the Pacific giant salamander (Dicamptodon tenebrosus). Mol Ecol 2006, 15:2477-2487.

37. Pielou EC: After the Ice Age: The Return of Life to Glaciated North America. Chicago: The University of Chicago Press; 1991.

38. Zink RM, Dittmann DL: Gene flow, refugia, and evolution of geographic-variation in the song sparrow (Melospiza melodia). Evolution 1993, 47:717-729.

39. Topp CM, Winker K: Genetic patterns of differentiation among five landbird species from the Queen Charlotte Islands, British Columbia. Auk 2008, 125:461-472

40. Wake DB: Incipient species formation in salamanders of the Ensatina complex. Proc Natl Acad Sci U S A 1997, 94:7761-7767.

41. Wilke T, Duncan N: Phylogeographical patterns in the American Pacific Northwest: lessons from the arionid slug Prophysaon coeruleum. Mol Ecol 2004, 13:2303-2315. 
42. Kuchta SR, Tan AM: Isolation by distance and post-glacial range expansion in the rough-skinned newt, Taricha granulosa. Mol Ecol 2005, 14:225-244.

43. Janzen FJ, Krenz JG, Haselkorn TS, Brodie ED Jr, Brodie ED III: Molecular phylogeography of common garter snakes (Thamnophis sirtalis) in western North America: implications for regional historical forces. Mol Ecol 2002, 11:1739-1751.

44. Taylor EB, Foote CJ, Wood CC: Molecular genetic evidence for parallel lifehistory evolution within a Pacific salmon (sockeye salmon and kokanee, Oncorhynchus nerka). Evolution 1996, 50:401-416.

45. Bretz JH: The Lake Missoula floods and the channeled scabland. J Geol 1969, 77:505-543.

46. McKee B: Cascadia: The Geologic Evolution of the Pacific Northwest. New York: McGraw Hill; 1972

47. Baldwin EM: Geology of Oregon. 3rd edition. Kendall/Hunt: Dubuque, IA; 1981.

48. Baker VR: The channeled scabland: a retrospective. Annu Rev Earth Planet Sci 2009, 37:393-411.

49. Maughan OE, Edmunson EE, Farris AE, Wallace RL: A comparison of fish species above and below Palouse Falls, Palouse River, Washington-Idaho. Quaternary Sci 1980, 54:5-8.

50. Miller MP, Bellinger MR, Forsman ED, Haig SM: Effects of historical climate change, habitat connectivity, and vicariance on genetic structure and diversity across the range of the red tree vole (Phenacomys longicaudus) in the Pacific Northwestern United States. Mol Ecol 2006, 15:145-159.

51. Oviatt CG: Lake Bonneville fluctuations and global climate change. Geology 1997, 25:155-158.

52. Johnson JB: Evolution after the flood: phylogeography of the desert fish Utah Chub (Gila atraria). Evolution 2002, 56:948-960.

53. Link PK, Kaufman DS, Thackray GD: Field Guide to Pleistocene Lakes Thatcher and Bonneville and the Bonneville Flood, Southeastern Idaho. In Guidebook to the Geology of Eastern Idaho. Edited by Hughes SS, Thackray GD. Pocatello: Idaho Museum of Natural History; 1999:251-266.

54. Hubbs CL, Miller RR: The Zoological Evidence: Correlation Between Fish Distribution and Hydrographic History in the Desert Basins of the Western United States. In The Great Basin, With Emphasis on Glacial and Postglacial Times. Bulletin of the University of Utah 38(20); 1948: Biological Series, vol. X, no. 7. 1948:17-166

55. Houston DD, Shiozawa DK, Riddle BR: Phylogenetic relationships of the western North American cyprinid genus Richardsonius, with an overview of phylogeographic structure. Mol Phylogenet Evol 2010, 55:259-273.

56. Houston DD, Belk MC: Geographic variation in somatic growth of redside shiner. TAm Fish Soc 2006, 135:801-810.

57. Houston DD, Shiozawa DK, Riddle BR: The roles of Neogene geology and late Pleistocene lake levels in shaping the genetic structure of the Lahontan redside shiner Richardsonius egregius (Teleostei: Cyprinidae). Biol J Linn Soc 2011, 104:163-176.

58. Smith GR: Fishes of the Pliocene Glenns Ferry Formation, southwest Idaho, University of Michigan. Univ Mich Pap Paleontology 1975, 14:1-68.

59. Broughton JM: Terminal Pleistocene fish remains from Homestead Cave, Utah, and implications for fish biogeography in the Bonneville Basin. Copeia 2000, 2000:645-656.

60. Smith GR, Dowling TE: Correlating Hydrographic Events and Divergence Times of Speckled Dace (Rhinichthys: Teleostei: Cyprinidae) in the Colorado River Drainage. In Late Cenozoic Drainage History of the Southwestern Great Basin and Lower Colorado River Region: Geologic and Biotic Perspectives. Edited by Reheis MC, Hershler R, Miller DM. Geological Society of America Special Paper 439; 2008: 208:301-317.

61. Houston DD, Ogden TH, Whiting MF, Shiozawa DK: Polyphyly of the Pikeminnows (Teleostei: Cyprinidae) inferred using mitochondrial DNA sequences. Trans Am Fish Soc 2010, 139:303-315.

62. Broughton RE, Reneau PC: Spatial covariation of mutation and nonsynonymous substitution rates in vertebrate mitochondrial genomes. Mol Biol Evol 2006, 23:1516-1524.

63. Gilles A, Lecointre G, Miquelis A, Loerstcher M, Chappaz RM, Brun G: Partial combination applied to phylogeny of European cyprinids using the mitochondrial control region. Mol Phylogenet Evol 2001, 19:22-33.

64. Liu H, Chen Y: Phylogeny of the East Asian cyprinids inferred from sequences of the mitochondrial DNA control region. Can J Zool 2003, 81:1938-1946.
65. Doadrio I, Carmona JA: Phylogenetic relationships and biogeography of the genus Chondrostoma inferred from mitochondrial DNA sequences. Mol Phylogenet Evol 2004, 33:802-815.

66. Sasaki T, Kartavtsev YP, Chiba SN, Uematsu T, Sviridov W, Hanzawa N: Genetic divergence and phylogenetic independence of Far Eastern species in subfamily Leuciscinae (Pisces: Cyprinidae) inferred from mitochondrial DNA analyses. Genes Genet Syst 2007, 82:329-340.

67. Dowling TE, Naylor GJP: Evolutionary relationships of minnows in the genus Luxilus (Teleostei: Cyprinidae) as determined from cytochrome b sequences. Copeia 1997, 1997:758-765.

68. Meyer A, Morrissey JM, Schartl M: Recurrent origin of a sexually selected trait in Xiphophorus fishes inferred from a molecular phylogeny. Nature 1994, 368:539-542.

69. Ptacek MB, Breden F: Phylogenetic relationships among the mollies (Poeciliidae: Poecilia: Millienesia group) based on mitochondrial DNA sequences. J Fish Biol 1998, 53:64-81.

70. Posada D: jModelTest: phylogenetic model averaging. Mol Biol Evol 2008, 25:1253-1256.

71. Jobb G: Treefinder. Version of 2008, Munich Germany. 2008, www.treefinder.de.

72. Huelsenbeck JP, Ronquist F: MrBayes: bayesian inference of phylogenetic trees. Bioinformatics 2001, 17:754-755.

73. Rambaut A, Drummond AJ: Tracer: MCMC trace analysis package version 1.5. 2007, http://beast.bio.ed.ac.uk/Tracer.

74. Clement M, Posada D, Crandall KA: TCS: a computer program to estimate gene genealogies. Mol Ecol 2000, 9:1657-1660.

75. Kauwe JSK, Shiozawa DK, Evans RP: Phylogeographic and nested clade analysis of the stonefly Pteronarcys californica (Plecoptera: Pteronarcyidae) in the western USA. J N Am Benthol Soc 2004, 23:824-838.

76. Drummond A, Rambaut A: BEAST: bayesian evolutionary analysis by sampling trees. BMC Evol Biol 2007, 7:214.

77. Tang Q, Liu H, Mayden R, Xiong B: Comparison of evolutionary rates in the mitochondrial DNA cytochrome $b$ gene and control region and their implications for phylogeny of the Cobitoidea (Teleostei: Cypriniformes). Mol Phylogenet Evol 2006, 39:347-357.

78. Salzburger W, Brandstatter A, Gilles A, Parson W, Hempel M, Sturmbauer C, Meyer A: Phylogeography of the vairone (Leuciscus souffia, Risso 1826) in Central Europe. Mol Ecol 2003, 12:2371-2386.

79. Rambaut A, Suchard MA, Xie D, Drummond AJ: Tracer v1.5. 2013, Available from [http://beast.bio.ed.ac.uk/Tracer]

80. Drummond AJ, Rambaut A, Shapiro B, Pybus O: Bayesian coalescent inference of past population dynamics from molecular sequences. Mol Biol Evol 2005, 22:1185-1192.

81. Ho SYW, Shapiro B: Skyline-plot methods for estimating demographic history from nucleotide sequences. Mol Ecol Resour 2011, 11:423-434.

82. Ore HT, Reid TV, Link PK: Pre-Bonneville-level, catastrophic overflow of Plio-Pleistocene Lake Bonneville; south of Rockland, Idaho. Northwest Geology 1996, 26:1-15.

83. Nishizawa S, Currey DR, Brunelle A, Sack D: Bonneville basin shoreline records of large lake intervals during Marine Isotope Stage 3 and the Last Glacial Maximum. Palaeogeogr Plaeod 2013, 386:374-391.

84. Brunsfeld SJ, Sullivan J: A multi-compartmental glacial refugium in the northern Rocky Mountains: evidence from the phylogeography of Cardamine constancei (Brassicaceae). Conserv Genet 2006, 6:895-904.

85. Brown JR, Beckenbach AT, Smith MJ: Influence of pleistocene glaciations and human intervention upon mitochondrial-DNA diversity in white sturgeon (Acipenser-Transmontanus) populations. Can J Fish Aquat Sci 1992, 49:358-367.

86. Taylor EB, Pollard S, Louie D: Mitochondrial DNA variation in bull trout (Salvelinus confluentus) from northwestern North America: implications for zoogeography and conservation. Mol Ecol 1999, 8:1155-1170.

87. Steele CA, Carstens BC, Storfer A, Sullivan J: Testing hypotheses of speciation timing in Dicamptodon copei and Dicamptodon aterrimus (Caudata: Dicamptodontidae). Mol Phylogenet Evol 2005 36:90-100

88. MCPhail JD, Taylor EB: Morphological and genetic variation in northwestern longnose suckers, Catostomus catostomus: the Salish sucker problem. Copeia 1999, 1999:884-893.

89. Haynes CM, Muth RT, Wycoff LC: Range extension for the redside shiner, Richardsonius balteatus (Richardson), in the upper Colorado River drainage. Southwest Nat 1982, 27:223. 
90. Quist MC, Gerow KG, Bower MR, Hubert WA: Random versus fixed-site sampling when monitoring relative abundance of fishes in headwater streams of the upper Colorado River basin. North Am J Fish Manag 2006, 26:1011-1019.

91. Houston DD, Shiozawa DK, Smith BT, Riddle BR: Data from: investigating the effects of Pleistocene events on genetic divergence within Richardsonius balteatus, a widely distributed western North American minnow. Dryad Digital Repository [http://dx.doi.org/10.5061/dryad.k2c2p]

doi:10.1186/1471-2148-14-111

Cite this article as: Houston et al:: Investigating the effects of Pleistocene events on genetic divergence within Richardsonius balteatus, a widely distributed western North American minnow. BMC Evolutionary Biology 2014 14:111.

\section{Submit your next manuscript to BioMed Central and take full advantage of:}

- Convenient online submission

- Thorough peer review

- No space constraints or color figure charges

- Immediate publication on acceptance

- Inclusion in PubMed, CAS, Scopus and Google Scholar

- Research which is freely available for redistribution 